\title{
Presence of Type 1 Collagen Alpha-2 (COL1A2) (rs42524) Gene Polymorphism and Scar Tissue Formation in Different Areas of Head and Neck
}

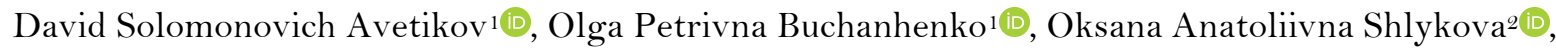 \\ Olga Vitaliivna Izmajlova ${ }^{2}$, Kateryna Petrivna Lokes ${ }^{1}{ }^{\circledR}$, Oksana Vasylivna Klitynska ${ }^{\circledR}$, Ludmila \\ Eduardivna Vesnina ${ }^{2}$, Igor Petrovich Kajdashevi[D

\begin{abstract}
${ }^{1}$ Department of Surgical Stomatology and Maxillo-Facial Surgery with Plastic and Reconstructive Surgery of Head and Neck, Ukrainian Medical Stomatological Academy, Poltava, Ukraine.

${ }^{2}$ Research Institute of Genetic and Immunological Foundations of Pathology and Pharmacogenetics Development, Ukrainian Medical Stomatological Academy, Poltava, Ukraine.

${ }^{s}$ Department of Stomatology of Child Age, Uzhgorod National University, Uzhgorod, Ukraine.

${ }^{4}$ Ukrainian Medical Stomatological Academy, Poltava, Ukraine.
\end{abstract}

Author to whom correspondence should be addressed: Kateryna P. Lokes, Ukrainian Medical Stomatological Academy, Department of Surgical Stomatology and Maxillo-Facial Surgery with Plastic and Reconstructive Surgery of Head and Neck, 23 Shevchenko Str., Poltava, 36000, Ukraine. Phone: +380 509796778. E-mail: lokes.ekaterina@gmail.com.

Academic Editors: Alessandro Leite Cavalcanti and Wilton Wilney Nascimento Padilha

Received: 29 May 2019 / Accepted: 19 December 2019 / Published: 27 January 2020

How to cite this article: Avetikov DS, Buchanhenko OP, Shlikova OA, Izmajlova OV, Lokes KP, Klitynska OV, Vesnina LE, Kajdashev IP. Presence of type 1 collagen alpha-2 (COL1A2) (rs42524) gene polymorphism and scar tissue formation in different areas of head and neck. Pesqui Bras Odontopediatria Clín Integr. 2020; 20 :e4422. https://doi.org/10.1590/pboci.2020.031

\begin{abstract}
Objective: To determine the effect type I collagen gene polymorphism alpha-2 (COL1A2) (rs42524) on the formation of scar tissue that is localized in the head and neck areas. Material and Methods: Sixty patients with scars in different areas of the head and neck were examined. The patients were divided into four subgroups, according to the types of scarring: G I: 15 patients with normotrophic scars; G II: 15 patients with atrophic scars; G III: 15 patients with hypertrophic scars; and G IV: 15 patients with keloid scars. The age of patients ranged from 17 to 54 years. The single-nucleotide polymorphic site of the COL1A2 (rs42524) gene was detected by a polymerase chain reaction and subsequent analysis of restriction fragment lengths. Pearson's chi-squared test with Yates's correction and Fischer's exact test were used. Results: There were no significant changes between the control and basic groups $(p=0.83)$ at analyzing the frequencies of $\mathrm{G}$ and $\mathrm{C}$ alleles. For the $\mathrm{G}$ allele, the calculation of odds ratio between the basic and control groups was 0.93 at $95 \%$ confidence interval (CI) (0.50-1.75), for the C allele - OR was 1.07 at $95 \%$ CI (0.572.01). Conclusion: Our studies may indirectly indicate the activation of the skin's protective reaction to physiological scarring and dosed scar formation in different areas of the head and neck.
\end{abstract}

Keywords: Pathology, Oral; Cicatrix; Collagen Type I; Polymorphism, Genetic. 


\section{Introduction}

The formation of pathological scars is inextricably linked to the disorder in the ratio between the components of the intercellular matrix and type I collagen. The disruption in the structure of the latter induces the development of a "respiratory burst" in the damaged skin [1-3].

Type I collagen is a predominant extracellular matrix component of fibrous origin. The balance between extracellular matrix synthesis and its degradation is disturbed in many pathological conditions, which leads to abnormal remodeling [4,5]. The remodeling of the extracellular matrix is a complicated and rigidly regulated process that occurs during wound healing. Wound healing depends on a balanced immune reaction and the interaction of matrix elements and collagen [6-8].

One of the causes of collagen dysfunction is the polymorphism of genes that encode it [9]. However, there are very limited data on the significance of gene polymorphic variant of type I collagen in the formation of pathological conditions of the skin. Some studies have shown an association of the COL1A1 polymorphism with the development of skin lesions in leishmaniasis in the Brazilian population [4]. Other studies indicate changes in connective tissue in the skin specimens of patients with intracranial aneurysms (IA). On the basis of this data, it was assumed that genes that participate in collagen biosynthesis might be among those, which predispose susceptibility to the development of intracranial aneurysm [10].

Currently, a clear link between the type I collagen alpha-2 (COL1A2) (rs42524) gene polymorphism and formation of intracranial aneurysms in the German population [11] and the residents of Northern China [12] has been established. A previous study showed that Ala549Pro SNP encoding in exon 28 (COL1A2) (rs42524) has an influence on the collagen structure with possible consequences for vessel integrity and tendency to IA [13].

The aim of this research was to determine the effect type I collagen gene polymorphism alpha-2 (COL1A2) (rs42524) on the formation of scar tissue that is localized in the head and neck areas.

\section{Material and Methods}

Sample

In order to study the COL1A2 (rs42524) gene polymorphism, 60 patients with scars in different areas of the head and neck were examined. Patients underwent treated at the Department of Maxillofacial Surgery of Poltava Regional Clinical Hospital. These patients formed the basic group of the study and the control group included 52, apparently healthy subjects. The patients of the basic group, according to the types of scarring, were divided into four subgroups: GI - 15 patients with normotrophic scars; G II - 15 patients with atrophic scars; G III - 15 patients with hypertrophic scars; G IV - 15 patients with keloid scars. The age of patients ranged from 17 to 54 years.

All clinical diagnoses (in all groups of patients) were confirmed morphologically at the previous stage of examination. The basic group did not include patients with general somatic diseases, cardiovascular pathology, and pathology of the gastrointestinal tract.

\section{Data Collection}

The single-nucleotide polymorphic site of the COL1A2 (rs42524) gene was detected by polymerase chain reaction and subsequent analysis of restriction fragment lengths in the reaction mixture containing: 2.5 $\mathrm{ml} 10 \mathrm{x}$ Buf for amplification; $2 \mathrm{mM}$ of magnesium chloride; $0.2 \mathrm{mM}$ of each dNTP; 10 picogram of specific primers; 2.5 units of DNA polymerase Tag; $20 \mathrm{ng}$ of genomic DNA. 
The amplification was carried out on the Tercyk amplifier (NGO "DNA Technology", Russia). Polymerase chain reaction (PCR) conditions were: initial denaturation at $94^{\circ} \mathrm{C}$ for 7 minutes, then 35 cycles of denaturation at $94^{\circ} \mathrm{C}$ for 30 seconds, annealed at $53^{\circ} \mathrm{C}$ for 30 seconds, and synthesis at $72^{\circ} \mathrm{C}$ for 30 seconds, final synthesis at $72^{\circ} \mathrm{C}$ for 7 minutes.

The identification of alleles was carried out by restricting the analysis of amplicons using restriction endonuclease Bsa JI (SibEnzim, Moscow, Russia). The cleavage products of the gene polymorphic region were detected by electrophoresis in $2 \%$ agarose gel in 1 x TBE (50 mM Tris-H3BO3 and 2 mM EDTA, pH 8.0) (for 2 hours at a voltage of $2 \mathrm{~V}$ per $1 \mathrm{~cm}$ of gel). The gels were colored with ethidium bromide with subsequent visualization of the results in UV light. As a result of restriction, the following fragments were obtained: for samples with homozygous alleles C (128 bp in length), homozygous alleles G (107 and 21 bp in length), while the heterozygous ones had fragments of 128, 107, and 21 bp in length.

\section{Data Analysis}

Statistical processing of data was performed using the Statistica 6.0 software package (StatSoft Inc., USA). To verify the statistical significance of the differences in frequency indices, Pearson's chi-squared test with Yates's correction and Fischer's exact test were used. The significance level was set at 5\%.

Ethical Aspects

This research project was approved by the Ethics Research Committee of the Ukrainian Medical Stomatological Academy. Voluntary participation and informed consent forms were received from all patients.

\section{Results}

The distribution of frequencies of the COL1A2 (rs42524) polymorphism genotypes for the basic and control groups is presented in Table 1.

Table 1. The intra-group analysis of frequency distribution of the COL1A2 (rs42524) genotypes.

\begin{tabular}{|c|c|c|c|}
\hline \multirow[t]{2}{*}{ Groups } & \multicolumn{2}{|c|}{ Distribution of Genotypes } & \multirow[b]{2}{*}{ p-value } \\
\hline & Observed & HWE & \\
\hline \multicolumn{4}{|l|}{ Control } \\
\hline $\mathrm{GG}(\mathrm{n}=31)$ & 0.596 & 0.607 & 0.66 \\
\hline $\mathrm{GC}(\mathrm{n}=19)$ & 0.365 & 0.344 & \\
\hline $\mathrm{CC}(\mathrm{n}=2)$ & 0.038 & 0.049 & \\
\hline \multicolumn{4}{|l|}{ Basic } \\
\hline $\mathrm{GG}(\mathrm{n}=35)$ & 0.583 & 0.588 & 0.85 \\
\hline $\mathrm{GC}(\mathrm{n}=22)$ & 0.367 & 0.358 & \\
\hline $\mathrm{CC}(\mathrm{n}=3)$ & 0.050 & 0.054 & \\
\hline
\end{tabular}

The distribution of genotypes in both study groups corresponded to the theoretically expected one at Hardy-Weinberg equilibrium (HWE). There were no significant changes between the control and basic groups $(\mathrm{p}=0.83)$ at analyzing the frequencies of $\mathrm{G}$ and $\mathrm{C}$ alleles (Table 2). The calculation of the odds ratio (OR) between the basic and control groups did not show reliable association with the development of scar tissue in different areas of the head and neck. For the $\mathrm{G}$ allele, it was 0.93 at $95 \%$ confidence interval (CI) (0.50-1.75), for the allele $\mathrm{C}-\mathrm{OR}$ was 1.07 at $95 \% \mathrm{CI}$ (0.57-2.01). 
Table 2. The comparison of alleles frequencies of the COL1A2 (rs42524) gene in basic and control groups.

\begin{tabular}{cccccc}
\hline Alleles & Basic Group & Control Group & p-value & \multicolumn{2}{c}{ CR } \\
& & & & Index & $95 \%$ CI \\
\hline G & 0.767 & 0.779 & 0.83 & 0.93 & $0.50-1.75$ \\
C & 0.233 & 0.221 & & 1.07 & $0.57-2.01$ \\
\hline
\end{tabular}

It was also studied the relationships between the polymorphic genotypes of the COL1A2 (rs42524) gene and the results of ultrasound examination among the patients of the basic group. They were divided into 4 groups of observation according to the scarring type (Table 3). In each group, we compared the indices of patients with the GG genotype and patients with the combined GC + CC genotype (allele C carriers). The GG genotype was detected in $12(80 \%)$ people and the combined GC+CC genotype - in $3(20 \%)$ patients of the study group with normotrophic scars. Ten subjects (66.7\%) had the GG genotype and five subjects (33.3\%) the $\mathrm{GC}+\mathrm{CC}$ genotype in the group with atrophic scars. The correlation of the GG genotype and the combined $\mathrm{GC}+\mathrm{CC}$ genotype in groups with keloid and hypertrophic scars did not virtually differ. There were 8 (53.3\%) and 7 subjects $(46.7 \%)$ with keloid scars; 7 (46.7\%) and 8 (53.3\%) subjects with hypertrophic scarring, respectively.

Table 3. Correlation between the genotypes of COL1A2 (rs42524) polymorphism and the data of ultrasound examination of patients with different types of scarring.

\begin{tabular}{|c|c|c|c|c|c|}
\hline \multirow[t]{2}{*}{ Groups } & \multirow[t]{2}{*}{ Index } & \multicolumn{2}{|c|}{ Genotype of COL1A2 (rs42524) } & \multirow{2}{*}{ p-value } & \multirow{2}{*}{ CR $(95 \% \mathrm{CI})$} \\
\hline & & GG & $\mathrm{GC}+\mathrm{CC}$ & & \\
\hline \multirow[t]{6}{*}{ Normotrophic Scars } & $\mathrm{L} 1 / 2$ & & & 0.146 & 0.045 \\
\hline & $\geq 0.68$ & 1 & 2 & & $(0.002-1.066)$ \\
\hline & $\leq 0.68$ & 11 & 1 & & \\
\hline & $\mathrm{L} 3 / 4$ & & & 0.494 & 0.17 \\
\hline & $\geq 1.39$ & 3 & 2 & & $(0.01-2.56)$ \\
\hline & $\leq 1.39$ & 9 & 1 & & \\
\hline \multirow[t]{6}{*}{ Atrophic Scars } & $\mathrm{L} 1 / 2$ & & & 0.333 & 0.167 \\
\hline & $\geq 0.93$ & 2 & 3 & & $(0.016-1.77)$ \\
\hline & $\leq 0.93$ & 8 & 2 & & \\
\hline & $\mathrm{L} 3 / 4$ & & & 0.577 & 1.0 \\
\hline & $\geq 0.99$ & 4 & 2 & & $(0.112-8.647)$ \\
\hline & $\leq 0.99$ & 6 & 3 & & \\
\hline \multirow[t]{6}{*}{ Hypertrophic Scars } & $\mathrm{L}_{1} / 2$ & & & 0.809 & 0.75 \\
\hline & $\geq 0.66$ & 4 & 4 & & $(0.11-5.26)$ \\
\hline & $\leq 0.66$ & 4 & 3 & & \\
\hline & $\mathrm{L} 3 / 4$ & & & 0.752 & 1.25 \\
\hline & $\geq 0.99$ & 3 & 3 & & (0.158-9.918) \\
\hline & $\leq 0.99$ & 5 & 4 & & \\
\hline \multirow[t]{6}{*}{ Keloid Scars } & $\mathrm{L}_{1} / 2$ & & & 0.201 & 0.13 \\
\hline & $\geq 0.81$ & 2 & 6 & & $(0.02-1.41)$ \\
\hline & $\leq 0.81$ & 5 & 2 & & \\
\hline & $\mathrm{L} 3 / 4$ & & & 0.809 & 2.22 \\
\hline & $\geq 0.89$ & 3 & 5 & & $(0.28-17.63)$ \\
\hline & $\leq 0.89$ & 4 & 3 & & \\
\hline
\end{tabular}

\section{Discussion}

The analysis of the obtained data did not reveal the relationship between the ultrasound index, which shows the nature of changes in the echogenicity of central and peripheral tissues of the scar in its middle zone 
$\left(\mathrm{L}_{1} / 2\right)$, and the ultrasound index, which shows the nature of changes in the echogenicity parameters in the medial and distal edges of the scar (L3/4) with genotypes of COL1A2 (rs42524) polymorphism in all four observation groups (Table 3). The lack of interconnection may be due to the small size of the specimen, which may lead to a less accurate determination of probability.

The study of the effect of the COL1A2 (rs42524) gene polymorphism on the development of IA has shown that the $\mathrm{C}$ allele can be an important risk factor for the development of this pathology [12]. Other studies have identified associations with the GC genotype in the German population [11] with a dominant model of GG+GC inheritance and family IA in the Japanese population, and it has been shown that this polymorphism induces the amino acid replacement of Ala with Pro at position 459 in the triple helix region. The Pro-459 peptide has higher temperature stability, which, according to the authors, can play a key role in the structural stability of collagen [13].

In our studies, we did not find associative relationships between the presence of the COL1A2 (rs42524) gene polymorphism and the scar tissue formation in patients with scars localized in different areas of head and neck. These data coincide with the data of German researchers who found that a number of morphological tissue anomalies in patients with IA and patients with the incision of the cervix were not associated with the SNP28 COL1A2 (rs42524) polymorphism. This data was obtained during the search of a possible association between $\mathrm{SNP} 28$ COL1A2 (rs42524) and the presence of abnormal ultrastructural morphology of collagen fibrils in the skin biopsy material [10].

\section{Conclusion}

We have obtained the data about the percentage content of the GG genotype in the group of patients with normotrophic scars, which was $80 \%$ that may be indirectly indicative of the activation of the skin's protective reaction to physiological scarring and dosed scar formation in different areas of head and neck.

\section{Authors' Contributions}

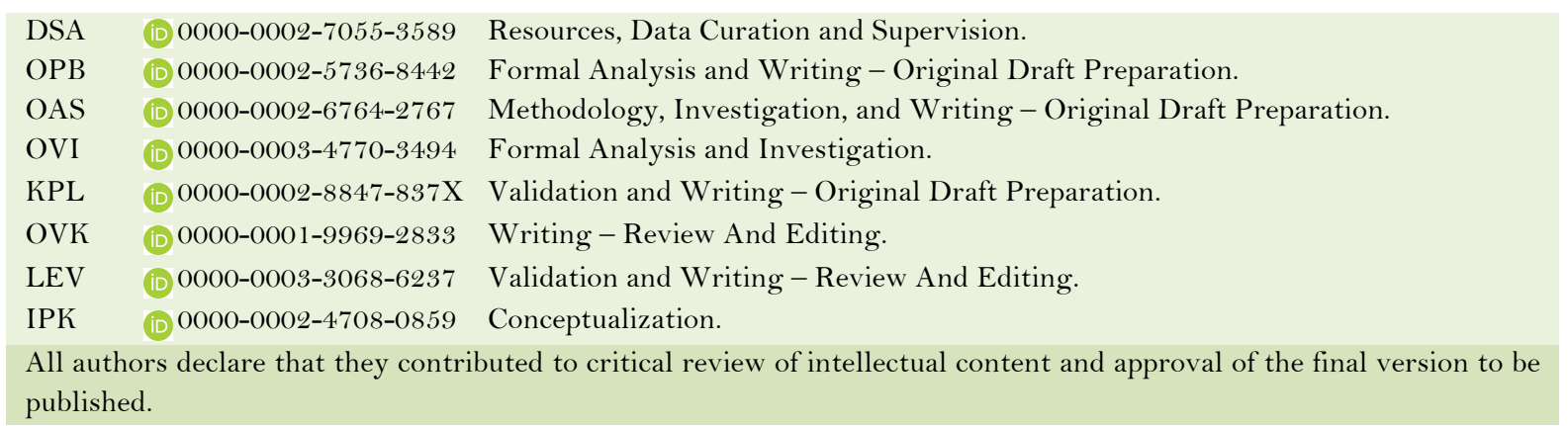

\section{Financial Support}

None.

\section{Conflict of Interest}

The authors declare no conflicts of interest.

\section{References}

[1] Ruksha TG, Aksenenko MB, Klimina GM, Novikova LV. Extracellular matrix of the skin: role in the development of dermatological diseases. Vestnik Dermatologii i Venerologii 2013; (6):32-9. 
[2] Loza KhO, Stavytskyi SO, Loza YeO, Voloshyna LI, Avetikov DS. Clinical characteristics of old cicatrical tissues after surgery. Klinichna khirurhiia 2016; 885:61-3.

[3] Avetikov DS, Bukhanchenko OP, Lokes KP, Yatsenko IV, Lokes-Krupka TP. Comparative characteristics of echogenous structure of postoperative normotrophic and atrophic cutaneous cicatrices. Klinichna Khirurhiia 2018; 85(5):44-6. https://doi.org/10.26779/2522-1396.2018.05.44

[4] Almeida L, Oliveira J, Guimaraes LH, Carvalho EM, Blackwell JM, Castellucci L. Wound healing genes and susceptibility to cutaneous leishmaniasis in Brazil: Role of COL1A1. Infect Genet Evol 2015; 30:225-9. https://doi.org/10.1016/j.meegid.2014.12.034

[5] Masuda Y, Ogura Y, Inagaki Y, Yasui T, Aizu Y. Analysis of the influence of collagen fibres in the dermis on skin optical reflectance by Monte Carlo simulation in a nine-layered skin model. Skin Res Technol 2018; 24(2):248-55. https://doi.org/10.1111/srt.12421

[6] Zhao HL, Zhang CP, Zhu H, Jiang YF, Fu XB. Autofluorescence of collagen fibres in scar. Skin Res Technol 2017; 23(4):588-92. https://doi.org/10.1111/srt.12375

[7] Avetikov D, Loza K, Starchenko I, Marushchak M, Loza O. Experimental-morfological substantion of exprediency to use the skin glue "Dermabond" for postoperative wound closure. Georgian Med News 2015; (244-245):90-3.

[8] Avetikov D, Buhanchenko O, Ivanitska O, Gavrilev V, Boiko I. The experience of using of digital systems for the diagnosis of hypertrophic scars of the facial skin. Visnyk Problem Biolohiyi i Medytsyny 2018; 1(142):243-6.

[9] Dalgleish R. The human type I collagen mutation database. Nucleic Acids Res 1997; 25(1):181-7. https://doi.org/10.1093/nar/25.1.181

[10] Arnold ML, Grond-Ginsbach C, Hausser I, Brandt T. Collagen morphology is not associated with the Ala549Pro polymorphism of the COL1A2 gene. Stroke 2005; 36(10):2068-9. https://doi.org/10.1161/01.str.0000185389.59049.75

[11] Gläsker S, Schatlo B, Klingler JH, Braun V, Spangenberg P, Kim IS, et al. Associations of collagen type I $\alpha 2$ polymorphisms with the presence of intracranial aneurysms in patients from Germany. J Stroke Cerebrovasc Dis 2014; 23(2):356-60. https://doi.org/10.1016/j.jstrokecerebrovasdis.2013.04.038

[12] Wu P, Li B, Wu A, Wang Y. Is type I alpha 2 collagen gene responsible for intracranial aneurysm in Northeast China? Neural Regen Res 2013; 8(5):445-51. https://doi.org/10.3969/j.issn.1673-5374.2013.05.008

[13] Yoneyama T, Kasuya H, Onda H, Akagawa H, Hashiguchi K, Nakajima T, et al. Collagen type I alpha2 (COL1A2) is the susceptible gene for intracranial aneurysms. Stroke 2004; 35(2):443-8. https://doi.org/10.1161/01.STR.0000110788.45858.DC 